\title{
Socio-Political Engagement of Contemporary Javanese Literature
}

\author{
Yosep B. Margono-Slamet \\ yosep-bambangms@untagsmg.ac.id \\ English Department, \\ Faculty of Languages and Culture, \\ The University of 17 Agustus 1945 Semarang, Indonesia
}

\begin{abstract}
This paper analyzes four selected short stories in Javanese literature entitled "Durmogati" by Budianto, "Maju Tatu Mundur Ajur" ("Damned if One Does, Damned if One Doesn't") by Budiono, "Bojo" ("Wife") and "Apik Meneng" ("It's Better to be Silent") by Harjono which were all published in 2018. In Indonesia, Javanese literature-together with other regional literatures - is a part of or complimentary to Indonesian literature but it has not received much attention at the national level, let alone at the international level. However, Javanese literature has not been less vocal than Indonesian literature. In this article, I will examine the sociopolitical engagements of the four short stories in Indonesian society. Using Phillips' ethnographic approach and Foucault's theory of power distribution, I will analyze how the four short stories are related to democracy, people's power, equality, and corruption in Indonesia after the fall of Suharto as the president of Indonesia in 1998. The analysis shows that the four short stories have significant socio-political engagements in the present Indonesia. The authors of the four short stories discussed in this paper show courage to blatantly criticize those who are in power. As such, the discussion of this essay offers fresh insights about contemporary Javanese literature and its role in the socio-political situation of the country. In the end, this essay will show that these four short stories are not only a reflection of Javanese society in particular and that of Indonesia in general but also as expressions of their authors as key informants about their society, i.e., how they see and think about the society in which they live.
\end{abstract}

Keywords: Javanese literature; socio-political engagement; democracy; power; equality

\section{INTRODUCTION}

Contemporary Javanese literature is often referred to as rural literature because most of these works portray the lives of rural people with all their everyday problems (Hutomo, 1997; Kristianawati, 2016). Scholars on this topic also emphasize the fact that Javanese authors in general, live in and come from villages. For more than three decades, during Indonesia's New Order regime from 1966 to 1998, very few Javanese authors' works criticized the regime. A few years before the fall of the New Order in 1998, contemporary Javanese literature started to undergo significant changes regarding their topics or subject matters. In addition to writing stories about the daily lives of rural people, many authors began to address the socio-political situation in Indonesia. I want to argue that the wind of reformation caused some Javanese authors to be transformed from being "sweet" to become "fierce." By "sweet" I mean that they were previously uncritical of those who were in power. Even if they wanted to criticize those in power, they did it very subtly. According to Hutomo (1997), if pre-reformation authors criticized those who were in power, their criticism was not political but a form of urun rembug (giving suggestion or having a discussion together). Hutomo's remark was about Javanese literary works published between the 1970s to the early 1990s before the 1998 reformation of Indonesia. The four stories I discuss here, all published in 2018, reflect the significant change that the reformation brought. 
Around the fall of the New Order regime, some Javanese authors started to criticize those in power blatantly and openly. At that time, literary works were not just a kind of art but also a way for the authors to express their social and political criticism. For example, in his novel, Sirah! (meaning "head"), published in 2001, Suharyono writes about a political chaos in Indonesia, i.e., conflicts that happened during an election campaign of a village chief. There were problems of collusion, money politics, and even black magic surrounding that campaign. My study of Javanese short stories published in Panjebar Semangat in 2003 (Margono, 2004) shows that many authors were very critical of those in power.

It is safe to say that Indonesia's reformation enabled Javanese literary authors to have a greater freedom of expression. They are no longer afraid of voicing injustice, suffering, and problems of wong cilik (common people). Issues of injustice, the gap between the haves and the have-nots, the oppression of the ruling class, corruption, democracy and political conflicts have become endless topics of their works. Widayat (2005) discusses succession in modern Javanese literature and in his analysis of one novel and four short stories, he found out that collusion and money politics thrive in modern, democratic Indonesia. This shows that there is active socio-political engagement in contemporary Javanese literary works. This subject has not been much studied within research in modern Javanese literature at the national and international levels.

This article is limited to the analysis of four short stories published in 2018 in Panjebar Semangat, one of the two Javanese weekly periodicals still in print today. The four short stories are Budianto's "Durmogati”, Budiono's "Maju Tatu Mundur Ajur" ("Damned if One Does, Damned if One Doesn't"), Harjono's "Bojo" ("Wife") and "Apik Meneng" ("It's Better to be Silent"). Irul S. Budianto (pseudonym of Khoirul Soleh), who is the author of "Durmogati", has a Bachelor in Literature. He was formerly a journalist for more than ten years and is now a civil servant living in Boyolali, Central Java. He has been publishing literary works in Javanese since 1989 (Riyanto, ed., 2019). Information on the other two authors, Budiono and Harjono however, is scarce because they are relatively new authors in the Javanese and Indonesian literary scene.

Literary works published in Panjebar Semangat-and in Jaya Baya, the other periodical - are considered to be standard Javanese literary works (Brata, 2003; Eswe, 1991; Hutomo, 1975, 1991, 1997) although not all works published here are of the same quality. In these four short stories, I analyze their socio-political content in the contexts of contemporary Indonesian society. Studying these four short stories may not be enough to generally describe the engagements of contemporary Javanese literature in the socio-political problems in Indonesia, but, at least, from this study, readers can gain insights that Javanese literature is worth studying also for its commentary on social and political issues in Indonesia.

\section{ENGAGED LITERATURE: AN INDONESIAN CASE}

Literature is almost always political, whether intended or otherwise. For Calinescu (1982), even if "... art has nothing to do with utilitarian values in general, and with politics in particular, is itself a political attitude ... the politics of antipolitics is the right politics in artistic matters, and perhaps in all other matters as well" (p. 123). In the history of the Indonesian literature, debates on whether or not literature should engage socio-political issues have been going on since the era of Balai Pustaka in the 1920s. Balai Pustaka was the state-owned publishing company that produced Indonesian and regional literatures. It was founded on August 15, 1908, in Jakarta. The debates escalated during the time of the Lekra (Lembaga Kebudayaan Rakjat) or People's Cultural Board, which was a left-wing cultural body. Lekra was a literary and social movement associated with the Indonesian Communist Party (PKI), founded in Jakarta on August 17, 1950, by D. N. Aidit, Njoto, A. S. Dharta, and M. S. Ashar. It ended in 1966 when General Soeharto 
prohibited the PKI as soon as he gained power. On the other hand, Manikebu, the abbreviation of Manifes Kebudayaan (Cultural Manifest), a declaration by a group of Indonesian writers and intellectuals in 1963 - among others were H. B. Jassin, Wiratmo Soekito, Trisno Sumardjo, Gunawan Mohammad - was in opposition to the Lekra (Susanti, Supriatna, \& Sumantri, 2019). Those authors believed that literature should uphold universal humanism. During the New Order era, the era during Soeharto's reign between 1966 and 1998, the debate did not cease. Readers will find that the Indonesian literature is a literature that is constantly engaged with all socio-political situations in its works. It is not one that has been alienated from its society and culture. Lekra authors, including Pramoedya Ananta Toer, used their literary works as propaganda (Suyatno, 2011). Meanwhile, from the point of view of the Manikebu authors, literary works must have universal values for all humanities. The left-wing authors championed the common people. However, not all authors in favor of ordinary people are categorized into left-wing authors. During the New Order Era, most authors were on the people's side due to the repression of the regime (Sumardjo, 2016; Taum, 2016).

The engagement of Indonesian literature with national issues dates back to the early $20^{\text {th }}$ century. Mas Marco Martodikromo (1890 - March 18, 1932), for example, was a vocal literary figure against the Dutch colonialist. Sumardjo (2016) notes that Martodikromo was a left-wing author who opposed the publication of literary works by Balai Pustaka. For him, Balai Pustaka's books directly or indirectly silenced the revolutionaries and tended to support the Dutch colonialist. Still, according to Sumardjo, literary figures in the era of Angkatan Pujangga Baru and Angkatan '45 (the abbreviation of 1945) prioritized the spirit of universal humanism. Angkatan Pujangga Baru was founded in 1933 by Armijn Pane, Amir Hamzah, and Sutan Takdir Alisjahbana who published their works in Pujangga Baru magazine. Later on, it was used to name the period of Indonesian literature after the era of Balai Pustaka. Meanwhile, Angkatan ' 45 refers to a period of Indonesian literature after Angkatan Pujangga Baru with Chairil Anwar, Asrul Sani, and Rivai Apin were among the outstanding figures.

In the glory days of Lekra in the beginning of the 1960s, Indonesian literature became very partisan. Literary engagements with political issues at the time reached an extreme, radical level because Lekra used it as a tool for propaganda to gain power. In the next era during the New Order, the authors of Lekra no longer published any works because Soeharto silenced them by imprisoning many of them. Interestingly, those who initially supported him eventually took the people's side and opposed the New Order (Sumardjo, 2016). The universal humanist authors initially assumed that the New Order was the better regime than the Old Order (during Soekarno's reign which ended in 1966) but later it turned out that the New Order was no different from the regime it had replaced. For many authors, the New Order was a militaristic, authoritarian regime which had to be resisted. More thorough research is still needed to discuss this topic but the following examples illustrate how authors were on the people's side.

Rendra, one of the most praised Indonesian poets, was well known for his resistance against the New Order regime. He became an icon of the opposition against the New Order. He consistently voiced the injustice that happened in Indonesia. Pratiwi, Safitri and Farika (2019) note that through his poems, Rendra opposed the New Order regime for repressing the people and for causing them to be poor and disadvantaged. A Chinese-Indonesian author, Clara $\mathrm{Ng}$, through her novel, Dimsum Terakhir (2006) expresses how the New Order repressed Chinese Indonesians. Even though the novel was published 8 years after the fall of the New Order, it is about the repression of the regime over the Chinese Indonesians. Budiman (2011) notes that it was not easy for women of Chinese descent to establish their identity during the New Order era. The state hegemony was so powerful, and the repression was so severe that people of Chinese descent, especially women, became marginalized.

Seno Gumira Ajidarma, in his anthology of short stories, Penembak Misterius (1993), gives a sharp critique against the New Order on the issues of human rights and socio-political 
problems in the country (Akbar, 2019). Okky Madasari, in her novel Entrok (2010), writes about the abuse of power of the New Order regime. The novel is about the hard life during the New Order regime, especially for women. Rokhmansyah (2015) argues that Madasari's work portrays corrupt and oppressive officials who damage the political and social order in Indonesia by committing corruption to enrich themselves, their families and cronies. Rokib (2015) notes that after the fall of the regime in 1998, Islamic literature began to emerge and flourish in Indonesia. This indicates that during the New Order, there were only a few religious literary works in Indonesia because the New Order repressed many areas of life, including religious life. It is reasonable to say that during the heyday of the New Order, Islamic literature became stagnant in the history of Indonesian literature.

\section{JAVANESE LITERATURE IN INDONESIA'S SOCIO-POLITICAL CONTEXT}

The engagement of Javanese literary authors in Indonesia's political context has actually been present since the early 1960s in the works of Suparto Brata (1932-2015), one of the most prolific Javanese authors who wrote from 1958 to 2013 and produced 135 books that include novels, plays, and scholarly articles on literature and 60 short stories (Jatmiko, 2016). In his short stories written within the decade, later compiled in an anthology titled Trem (2001), Suparto Brata wrote about the socio-political situation in Indonesia. In "Elinga Semangat 49" ("Remember the Spirit of 49"), "Wong Gede" ("A Powerful Person"), "Jam Malam" ("The Curfew") and "Pangigit-igit" ("Anger"), Suparto Brata delivered sharp criticism against corrupt and oppressive government officials (Margono, 2020). Because Javanese literature has not received much attention from experts or literary critics in Indonesia and from government officials, so far there has not been a specific study of the socio-political aspect of those short stories by Suparto Brata.

Javanese literature, along with other regional literature in Indonesia, uses the local language, i.e., the Javanese language, as its medium. In this regard, Quinn states that Javanese literature "had been greeted with silence at the national level" (1983, p. 1). Like other regional literature, Javanese literature is only considered as a part of or a complementary to Indonesian literature. It is not considered important in the national context (Atmowiloto, 1989; Sumardjo, 1991). As a result, Javanese literature does not receive the recognition and support it deserves even from the Javanese community. Many Javanese authors are afraid that modern Javanese literature would become extinct. Kristianawati (2016) considers modern Javanese literature to be dead. Although there is a greater level of literacy now amongst the Javanese and Indonesian society due to advancement of education and technology, the use of Javanese language is mostly for oral communication. In terms of written communication, Javanese peopleincluding students at any level - mostly use the Indonesian language (Suharyo, 2018). Even most works on Javanese literary criticism is written in the Indonesian language, not in Javanese. In addition, there used to be many newspaper publications and weekly periodicals in the Javanese language but today there are only Panjebar Semangat and Jaya Baya. Both are weekly periodicals printed in Surabaya, East Java. This clearly tells us that less and less Javanese people read literary works in Javanese (Suharyo, 2018). Some culture observers and linguists have expressed worry that the Javanese language will become extinct in the future if there are no serious efforts to preserve it (Tondo, 2009).

In the past, other than Suparto Brata and Esmiet, almost no authors wrote stories concerning socio-political issues boldly in their works, let alone stories criticizing corrupt and oppressive rulers. As part of the Indonesian society, Javanese authors during the New Order era did not have the courage to address the socio-political situation in Indonesia because of the repression of the regime. They were afraid of the power of the New Order (Budiman, 2006; Darmaningtyas, 2005; and Gaus, 2009). The New Order regime systematically made all civil 
servants show mono loyalty to Golongan Karya (Golkar), the government political party. Civil servants were used as a machine to win the Golkar in every general election (Tanjung, 2007). Closer to the collapse of the New Order, this situation changed. Many Javanese authors started to write on the theme of socio-political situation.

To date, literary works that gained international and national attention because they criticized the social and political situation are all written in Indonesian. Even though Javanese authors published such works, they are not considered a threat by the ruling regime. However, works by Javanese authors do contain engagement and partisanship. Through their works, Javanese authors too, voice the injustice and suffering of common people who cannot speak for themselves. To a certain extent, their works are representations of the voices of marginalized people. In their works, authors describe Javanese common people as disadvantaged and marginalized. Tunggak-tunggak Jati, a novel by Esmiet (1977); Sirah!, a novel by AY Suharyono (2001) as mentioned previously, and Bledheg Segara Kidul, an anthology of poetry by Turiyo Ragilputra (2007), are among these kinds of works. It is at this point that literature is important as a corpus of socio-cultural research and not just an art form to be enjoyed for its aesthetics, language and literary values (Philips, 1987). However, due to its lack of recognition at both the national and international level, contemporary Javanese literature has not become subjects of scholarly studies in the socio-political context in Indonesia. According to Quinn (1992, p. 279) this is because "[ $[\mathrm{t}] \mathrm{hrough}$ its administrative arms, the Indonesian government has tended to promote the national language and culture at the expense of regional languages and cultures." Quinn (1992) suggests that it is the case because the Indonesian language is too dominant over the Javanese and other local languages in Indonesia. This happens due to the policy of the Indonesian government which regards Indonesian (Bahasa Indonesia) as the national language of the country. This is one of the main factors why Javanese language and literature are not popular amongst the younger generation of Javanese.

\section{THEORETICAL FRAMEWORK}

The theoretical frameworks used in this research are Phillips' ethnographic approach and Foucault's distribution of power. The main purpose of Phillips' ethnographic approach to literature is to analyze literary works for its manifestations of culture, including the social and political lives of a society or a nation. In this approach, literary figures can be "key informants" about their society because their positions in the society are important even though different from those of anthropologists because:

\footnotetext{
... the people for whom they are writing are obviously not foreigners but rather are people much like themselves. The communication taking place is totally intracultural. It is this fact that makes literature such a valuable corpus of knowledge for anthropological inquiry. What is being communicated - in content, meaning, assumption, and purpose — is, above all, "the native's point of view".

(Phillips 1987, p. 4)
}

In this paper I consider the authors of the four short stories as key informants of Javanese society, or at least of the society in which they live. Therefore, in Phillips' theory, they are sensitive, reflective, and articulate members of the Javanese society. Thus, literature is not only a reflection of a society but also an expression of its author. This theoretical framework is part of Wellek and Warren's (1948) views on the sociology of literature, comprising the sociology of the author, the work, and the readers. In this paper, however, I only focus on the sociology of the authors, in the sense of how they see and think about the relationships between the state and common people. 
The second theoretical framework used is Michel Foucault's view of the distribution of power. According to Foucault, power does not only exist in those who lead but also in those who are led. He disagrees with the idea that power is held by a person or group through acts of domination or coercion. Rather, he sees it as scattered and diffused. He wrote "Power is everywhere and comes from everywhere so in this sense it is neither an agent nor a structure" (1998, p. 63). As Foucault sees it, power constantly changes and negotiates. It is diverse and dispersed.

The two theoretical frameworks are of paramount importance for the discussion of the four short stories. The role of the authors as key informants about Javanese society is very important in understanding how they see, think about, and express their ideas about what is happening in their society. Foucault's distribution of power is helpful in understanding how power is distributed between those who have the authority and the people. Foucault's concept of power did not seem to work in the literature published during the New Order, but it does for literature in Indonesia at the present time. It is in these two frameworks that I discuss the four short stories.

\section{RESEARCH METHODOLOGY}

The method used in this research is the qualitative method. The primary data were taken from the four short stories I have mentioned above. The analysis will be conducted by using content analysis technique. Content analysis focuses on describing, interpreting and analyzing texts (Krippendorf, 2004). The analysis will be focused on the socio-political aspect of the four short stories.

Parts of the stories discussed will be presented in its original language and translated into English to show its socio-political engagement in the current situation in Indonesia. I will then analyze these excerpts based on the socio-political issues they try to address.

The choice of the four short stories is not random. I had the intention of analyzing short stories in the Javanese language that are related to the current social and political situation in Indonesia. For this purpose, I read short stories in Panjebar Semangat, published in 2018. I should have read 52 short stories but I could only find 43 periodicals of the 2018 edition. Thus, I read 43 short stories. I found that most of them are about love stories and daily problems of village lives. The four short stories discussed in this paper are outliers and thus they serve my purpose.

\section{DISCUSSION}

On a surface level, these short stories do not directly express the escalation of social and political issues in Indonesia. They reflect a variety of issues. The authors do not appear to oppose the authorities directly. But, as it often happens in the Javanese culture, the authors use sanepa, namely sentences or utterances that contain allusions, irony or sarcasm, throughout the stories they write. They signal that the authorities must pay attention to the people. In Java, common people do not necessarily have to voice their critiques of those in power directly. Instead, they might criticize the authority indirectly through symbols or metaphors and relate those to events that occur in daily lives, or they can even do it in silence. A protest or rebellion in the Javanese society used to be expressed quietly; it could even be expressed in silence. The people of Yogyakarta, for example, will do tapa pepe, sitting in front of the palace silently under the heat of the sun, when they are disappointed with the king. This is a form of resistance from common people similar to that of the peasants described by Scott (1985). It is in this context that these four stories are engaged with the socio-political life in Indonesia. 
Most contemporary Javanese authors are teachers and lower bureaucrats and most of them live in rural areas. According to Geertz (1960) they are priyayi not because they have noble descent but because they do "refined" (alus) work, not "unrefined" (kasar) one. Thus, they can be categorized into the elites if it means the richest, most powerful, best-educated, or best-trained group in a society (Cambridge Dictionary online, 2021). Javanese authors are not necessarily richer than other people; they should not be more powerful either. It goes without saying, however, that they have better education than most common people in their areas. In the past, Javanese priyayis, especially those of noble descent, did not always stand on the common people's side because of their interest in maintaining their positions and privileges. Today we can call the Javanese authors as the new priyayis because of their education and authorship. They take side with the common people through their works in literature. This is because they live among and with the common people and they are part of the same society. It is important to emphasize here what Hutomo (1997), a highly regarded Javanese literature scholar, author, and critic, says that modern Javanese literature is about the common people in rural areas, written by authors who mostly reside in rural areas. This is the context why they voice the sufferings or the problems of the common people in dealing with those who are in power. In Phillips' (1987) term, they are key informants of their society and culture because the literary works they create are inseparable from their social and cultural contexts (Wellek \& Warren, 1948). This is what the four short stories are about. The following is the discussion of each short story preceded by its short synopsis.

\section{"DURMOGATI"}

Durmogati is one of the 100 Korawas. The Korawas and the Pandawas are cousins. The Pandawas are the five sons of Pandu and the Korawas are the 100 sons of Pandu's older brother, Drestarastra. Pandu was once the king of Astina. When Pandu died, Drestarastra ascended the throne of Astina because the Pandawa brothers were still young children. He was supposed to give the throne to Yudistira, the oldest of the Pandawas, when the lad was ready. But when it was time to do so, he gave the throne to Duryudana, his oldest son, instead. Duryudana did not want to return the throne to the Pandawas. From that point on, they became great enemies. The Korawas had planned to kill all the Pandawas in order to remain in power in Astina. If the Pandawas were all dead, the Korawas would not need to face the Baratayudha, the Great War destined by the gods for both parties. Durmogati, in every official meeting, never agreed with the policies of his brother, Duryudana, who was the king. Despite his oppositions to his brother, in the end Durmogati had accept his brother's decisions because he had no power.

In Javanese culture, wayang kulit or shadow puppet functions both as an entertainment as well as a moral guide. Javanese people believe that each character in the shadow puppet is a personification of human nature. Because wayang kulit is so important for the Javanese, many Javanese authors works are inspired by the plot and characters in these puppet performances. Budianto's "Durmogati" is one of them. By using some characters of a shadow puppet story plot, he criticizes the situation that happens in Indonesia's contemporary politics.

In Budianto's short story, Durmogati is said to incarnate into a different character and thus experiences a different fate. Harya Wibaksa, a rich and powerful person in a village, hosts a shadow puppet show and requests the puppeteer to craft a story about the "evil" Korawas who want to eliminate the "good" Pandawas. The dhalang or the puppeteer has no other choice but to submit to the demand of Harya Wibaksa. The dhalang must tell a story in which Durmogati protests against the king's wish as he does not want to carry out his order. Durmogati reminds the king that the decision is not right. Sadly, Durmogati is expelled from the kingdom for going against the king. Durmogati's expulsion makes the audience angry because the story deviates from the age-old convention of the plot of that performance. But the 
dhalang tells that twisted plot because it is requested by the patron, Hary Wibaksa. The people protest and want to stop the puppet show because it is not in accordance with the pakem or the standard plot. The unconventional plot of "Durmogati" enrages the audience and, led by Dul Sableng, a brave character in the story, they protest:

\footnotetext{
“Toblas, toblas, dhalange melu-melu ora urus. Ora nggenah!” tembunge Dul Sableng keprungu rada banter.

"Gek dhalange dibayar pira karo sing duwe gawe nganti gelem nyebal kaya ngono," semaute Min Klemuk sajak getem-getem.

"Jan ora cetha tenan! Iki wayangan cara ngendi?!" Lik Kumbang sing biyasane ora duwe gunem melu pegel.

"Yen dhalange wis gelem disetir dening sing mbayari cetha bakal gawe rusake pakem pakeliran," kandhane Dul Sableng kandheg sedhela.

(Budianto, 2018, p. 24)

(“Oh my God, the puppeteer is nuts. He's crazy!" Dul Sableng said loudly.

"How much does he get paid so that he is telling such a crazy story," shouted Min Klemuk angrily.

"It's a mess; it really is! What kind of shadow puppet performance is this?!" Lik Kumbang, who usually was quiet, also expressed his anger.

"If the puppeteer is doing everything the patron asks him to do, then he will destroy the story," Dul Sableng said and then paused briefly).
}

Harya Wibaksa silences them by calling the police. The police are assigned to maintain order and act quickly to arrest the protesters. The dissatisfied and angry audience believes that Harya Wibaksa is the one who deliberately masterminds the disruption of the narrative of the puppet show. They also believe that he has caused all bad and chaotic events in their village. But as soon as they protest, the policemen suppress and disperse them. Harya Wibaksa is satisfied. For him, common people will never endanger him because he is the ruler of the community. He can do anything to create chaos.

The short story, "Durmogati", does not capture everything that happens sociopolitically in Indonesia, but at least the characters of Harya Wibaksa, Dul Sableng, Min Klemuk and his friends as shown in the quotation above show that dirty politics does not only occur in Jakarta but has penetrated into the village and into the lives of people at all levels of society. Power, then, does not only exist at the level of the central government, but, as Foucault says, happens everywhere. The distribution of power, large or small, occurs at all levels. Harya Wibaksa may be the richest and most powerful person in the whole village, but common people have the courage to voice their aspiration even though they are defeated in the end. On a larger scale, "Durmogati" is a story about the contemporary social and political situation in Indonesia.

The conflict between the Korawas and the Pandawas is a conflict related to power. This is not merely a conflict between good and evil but a conflict of morality. Anderson (1965), Brandon (1970), Geertz (1960), and Magnis-Suseno (1988) agree that the conflict between them is complicated. The Pandawas are not always good and the Korawas are not always evil. Durmogati, for example, is a good character but, unfortunately, he lives in Astina where Duryudana, the power-hungry king, rules and does not want to give the throne to Yudistira, the rightful heir of Pandu. Both the Korawas and the Pandawas have goodness as well as flaws in them. This story presents the different facets of humanity which includes a combination of both positive and negative characters and also highlights how issues of power, ethics and morality affect people's characters and decision-making. It highlights a narrative found in society and politics not only in Java and Indonesia but all over the world. 


\section{“MAJU TATU MUNDUR AJUR” (“DAMNED IF ONE DOES, DAMNED IF ONE DOESN’T”)}

Budiono's "Maju Tatu Mundur Ajur" ("Damned if One Does, Damned if One Doesn't") is about Gendhon Paidi, a successful businessman, who runs for a member of the Regional House of Representatives. Some people persuade him to do so with a promise that they will do anything to help him. Titik Paidi, his wife, does not agree with the idea, but he presses on. The plot thickens as Gendhon spends almost all his money to bribe people during the campaign. People come and go praising him as they take the bribe money. Titik becomes more and more miserable. The story ends with Gendhon losing all his money for the campaign. His wife is so sad, helpless, and devastated.

It is natural for one to feel dissatisfied with his or her life. Gendhon Paidi, the main character, wants to climb the social and economic ladder to the highest rung. Wanting more than just being financially affluent, he also hungers for power, thinking that it will make people respect him. Therefore, he wants to run for a member of parliament, as seen at the beginning of this story:

Gendhon Paidi mesem sumringah. Ulate katon bingar. Mbayangake suk nek wis kelakon dadi anggota DPRD Kabupaten, hmmm, saiba luwih kajen keringan uripe. Neng endi-endi tansah disubya-subya konstituen samangsa mudhun ing dapil-e. Saben-saben rapat komisi utawa sidhang paripurna nganggo setelan jas legislatif mesthi ketok tambah gagah merbawani. Apa maneh yen pas reses, ngalor-ngidul nyerep aspirasi numpak mobil mewah sing ditempleki logo DPRD. Jelas beda rasane.

(Budianto, 2018, p. 23)

(Gendhon Paidi smiled brightly. He looked radiant. He already imagined becoming a member of the Regional House of Representatives and his life would be much different. He imagined that his life would be much better after he became a member of the Regional House of Representatives. Going everywhere, he would be praised by his constituents. On every single commission meeting or plenary session, he would wear a formal suit so that he would look prestigious and commanding. During the recess, he would come to visit his constituents by an official car with the House of Representatives logo to listen to their aspiration. It would be clearly different).

Gendhon Paidi is a portrait of some people in today's Indonesia. During the New Order regime, the social and political situations in Indonesia were calm on the surface. However, under the surface serious turmoil was brewing all the time. Due to the strong repression from the regime, the turmoil was muffled and invisible to the common people. When Indonesia entered the reformation era after the fall of Suharto in 1998, a clearer scene of the sociopolitical situation in Indonesia surfaced. Many people wanted to hold powers starting from the lowest level to the highest. Indonesia's political world became frenetic. Every citizen eligible to vote and be elected can express their political aspirations freely.

The fact that power is very tempting proves to be true in the reformed era of Indonesia. The main motivations of common people to become elected officials are wealth and fame. They think that the position of elected officials will give them many privileges. For one, they dream to become financially rich. This is one of the excesses of democratization in Indonesia. This situation is well depicted in contemporary Javanese literary works. In this story, Gendhon Paidi wants to become a government official even though he knows from the start that the path to power will be rocky. He must use up all his money. He does not know whether or not he will win the election. But one thing is sure: he has spent most of his money.

From the perspective of Indonesia's contemporary politics, this short story reflects reality. One who wants to be an elected official must spend a lot of money to buy people's votes. Unfortunately, no one can ever predict the result of the election. In Java, many people who are obsessed with power do not think wisely, as shown in the conversation between Gendhon Paidi and his wife: 
“Oh! Atiku tansah was sumelang, Pak. Ora penak rasane. Mengko gek ...?!”

"Kadhung nyemplung..."

"Iya nek dadi anggota dewan tenan. Isa d-3: duduk, diam, duwit! Kuwi wae durung karuwan balik modal. Nek ora dadi? Nyoro! Hik hik hik..." tangise sing wedok ambrol.

(Budianto, 2018, p. 24)

("Oh! I always worry about it, dear. Something seems to be wrong. What if ...?!"

"I have already been a half way doing this ..."

"If you are successful, it will be good. You will be able to just sit, be quiet, and receive salary as a member of the council. However, are you sure you can get what you have spent in return? What if you fail? It's going to be miserable!" she cried out).

The Javanese expression which is the title of this short story, "Maju Tatu Mundur Ajur" which means 'when you go on doing what you are doing you will be ruined and when you stop doing what you are doing you will also be ruined', accurately illustrates the predicament of Gendhon Paidi. It is told in the story that he is still unclear about the result of the election, but he has spent a large sum of money for the efforts. Proceeding or canceling his run in the election will have the same result: he is ruined financially. He has no choice. But for him, to withdraw from candidacy is no longer possible.

In the socio-political context of Indonesia, especially during the seasons of legislative election, many "Gendhon Paidis"-mostly people with insufficient political knowledge, education, or leadership skills — run for members of the House of Representatives. They are tired of becoming just regular people governed by those in power. They want to have power too. Many who do not have money will borrow from the bank or mortgage their land and house, or sell their property to fund their campaigns. They do not listen to the voice of reason which often comes from their spouses who remind them not to run for a position. There have been many examples in the Javanese society that obsession with power often results in misery. The longer the process of election takes, the more money they need to spend. It is likely for them to end up like Gendhon Paidi, who eventually has to lose almost all his possessions. In real life, this happened. In the 2019 general election, some people who failed to be elected suffered from mental disorders because they lost almost everything they had and were not elected; but some other people could recover from this loss and would run yet again for another election (Dwiastono \& Priambodo, 2019).

This short story is about how power becomes a dream or obsession for many people. Power enables people to do anything for their own benefit or for their relatives and friends. In contrast, only a few people think that power (or position) should be used to enrich the people or the society. At this point, the concept of power by Arendt (1970) is relevant. Power can motivate someone to gain something, or power is about how people can come together as a group to reach shared goals. The first will cause chaos in a society but the second will create harmony. The first has been a phenomenon in Indonesian politics since the fall of Soeharto in 1998 until now. Soeharto's resignation pushed for democratization, but democracy in Indonesia seems to be excessive because people think that they can have the absolute freedom and become rulers for the benefit of themselves, their families, and their groups. Mudjiharto (2020) argues that democracy in Indonesia is excessive because it results in chaos, anarchy, and liberalism.

\section{"BOJO" ("WIFE")}

"Bojo" ("Wife") by Harjono is about the chief of a village, Banuaji, and his wife. Larasati, the wife, does not want to live in poverty. She feels ashamed socializing with other women because she does not have jewelry, a car, or other luxuries. To have a better life, she encourages her husband to embezzle money from the treasury of the village. Banuaji does not agree with his 
wife's idea. But Larasati thinks that as the village chief, her husband can and should have the privileges to use the village's money so that they can have a decent, comfortable life. The virtuous Banuaji, is not the stereotypical, power-hungry village chief. Embezzling money is something he avoids at all costs because he always remembers his late father's teaching. Even though Larasati keeps asking him to do so, he never gives in.

According to International Transparency, Indonesia ranks $89^{\text {th }}$ out of 180 as the most corrupt countries in the world (Mazrieva, 2019). This issue is also a concern for Javanese authors, including Harjono. In this short story, he addresses this theme. He tells a story of corruption on the village level. It is no longer a secret that corruption in Indonesia can occur at all levels of government. One of the causes of corruption is the amount of costs that has been spent by government officials when they campaign to be elected. After becoming an elected official, the person must repay his debts and regain the money and property he has spent. Corruption is the quickest way to do that.

"Bojo" in many ways is contradictory to the typical plot and characters presented in Javanese literature. Banuaji, the main character of this short story, does not want to embezzle money from the village. The Komisi Pemberantasan Korupsi (Corruption Eradication Commission) confirms that in contemporary Indonesian society, one of the reasons for corruption by state officials is their spouses (Taher, 2019). In the story, Banuaji is different. Complaining of not having jewelry when going to a wedding party, Larasati says:

"Nggregah, Mas. Aja kaya sing uwis-uwis. Kaya wektu gawe carik dhek emben kae. Sampeyan rak wis tak wanti-wanti, kudu entuk bagiyan sing akeh. Paling ora satus yuta. Wong jabatan carik iku kanggo salawase urip. Nek ketemune sampeyan semuci-suci, semugih, emoh kalepatan dhuwit ngono iku, njur entek-entekane dhuwit patang atus yuta saka Harsudi calon carik ya dikruwes wong ndhuwur-ndhuwur kana," pamelehe Larasati ora tanggung-tanggung".

(Harjono, 2018a, p. 24)

("Come on, dear. Don't be stupid as you did in the past. Do you remember when there was an opening for the village secretary? I seriously told you that you had to get as much as one hundred million rupiahs. It's because the position of the village chief is a long life position. But you acted like an angel, like a rich man because you did not want the money. You know what? In the end the four hundred million rupiahs from Harsudi the candidate was divided among your bosses and you got nothing," said Larasati sharply.)

The excerpt above has multiple layers. First, according to Larasati, a government official must have a decent life. It is near the end of Banuaji's term, but Larasati still thinks that they are not financially comfortable. Second, we can see that Banuaji is so determined to keep his innocence. This is what I mean by the alternative narrative presented in this short story. In modern Javanese literature on this topic, an official is often told to have fallen into the temptation of corrupting money. But that is not the case with Banuaji. Third, whoever wants to become a government official in Indonesia, he or she must spend a lot of bribe money. Harsudi, who runs to be elected village secretary, spends 400 million rupiahs and it is not clear what the money is for. Banuaji has a say in the recruitment process of the secretary. If he will, he can get some of the 400 million rupiahs. According to Larasati, the 400 million rupiahs is finally divided up by Banuaji's superiors and his husband gets nothing. Answering to his wife who always wants him to commit corruption, Banuaji says:

"Aku tansah sumanggem marang wasiate Bapak, Dhik,” pamunggele Banuaji, “Aja liwat dalan sing nerak angger-angger lan linggar saka laku bener. Luwih becik mlaku sejangkah mbaka sejangkah waton katekan apa kang diarah".

(Harjono, 2018a, p. 24) 
("I always obey the teaching of my late father, dear," said Banuaji, "Do not go down the path that violates the law and do the wrongdoings. It is better to go a step by a step to reach your ultimate goal.")

This short story has a clear message: state officials should not commit corruption because corruption is detrimental to the people and country. They should not abuse their power but use it for the prosperity of the people.

\section{“APIK MENENG" (“IT'S BETTER TO BE SILENT")}

"Apik Meneng" ("It's Better to be Silent"), also by Harjono, has the narrator as the protagonist who admits that his father is not a good man. Not only does the father cut teakwood illegally but he also runs a timber business. To keep the business running, he bribes many government officials. The protagonist knows everything his father does, but he keeps silent. He also keeps silent when his father tells him to run for the village chief to succeed the retiring one. He runs face-to-face with the wife of the retired village chief for the post. In the end, he loses the election, and his father goes bankrupt, as his mother dies of a heart attack. Later, the father turns into a limestone mining business. The protagonist is also silent as his father destroys the environment. The story ends with the father's death of a freak accident at the quarry. The protagonist continues to remain silent even though he knows all his father's wrongdoings. But at the same time, he does not want to follow in his father's footstep. He is not responsible for whatever his late father did.

This short story, like the other three, is also about the social and political conditions in Indonesia. The setting of the story is in the rural area. It is likely that Harjono wants to convey that politics at all levels is the same. The father of the protagonist does illegal logging and has a furniture business because he gets his permit from certain government officials that he bribed. The permit is not an official but an informal one with a very high price tag.

This story is the protagonist's expression and attitude about corruption, abuse of power, and democratization. He just keeps quiet knowing whatever happens. In the Javanese culture, silence has many meanings: someone who is silent can be understood as having a lot of knowledge, being indeed quiet, being stupid, being ignorant, in the process of protesting, or being scared. The protagonist knows exactly that what his father and government officials do is wrong. He chooses to be silent because he does not want to defame his father's reputation, even though he knows that his family's wealth comes from illegal businesses:

Uripe kulawargaku kaya di-‘bim salabim.' Saka asil adol kayu jarahan bapak terus tuku truk kanggo nglancarake usahane. Ngangkut kayu jarahan saka njaban dhaerah, Blora lan Grobogan. Sabacute banjur tuku graji mesin adeg perusahaan kayu. Ngladeni pesenan omah, kusen, daun pintu, mebel lan liya-liyane. Kamangka miturut peraturan mesthine ora kena. Mosok ana perusahaan kayu kok awor alas? Nanging kena apa teka entuk izin usaha? Mulakna aku apik meneng.

Wiwit kuwi tak titeni. Pendhak kala mangsa bapak mesthi katekan tamu. Menawa ora butuh beselan temtu njejaluk sing ika, sing iki. Meja makan, kursi teras, dresoir, bangku taman apa meja ping pong. Wah, pokoke bapak kudu kurmat karo atur kesaguhan, "Siap, Boss!”.

(Harjono, 2018b, p. 23)

(The life of my family is like a magic. From the illegal logging, my father was able to buy trucks to carry the wood from Blora and Grobogan. Then he bought saws and established a timber company. He built houses and produced cabinets, door leaves, furniture and many more. These all were actually illegal. Why was there a wood company adjacent to the woods? Why was he granted a business permit? That's why it was better for me to be silent.

Since then I had been paying attention to everything going on. My father always had guests on a regular basis. They came to ask for money or furniture such as dining tables, patio 
chairs, wardrobes, garden chairs or ping pong tables. Well, my father had to respect and obey them and said, "Yes, Boss!")

The protagonist insists on choosing to be silent about everything that happens and with that silence he feels that he does not share his father's sin. In the Javanese culture, people generally subscribe to what can be considered karmic or fatalist beliefs that ultimately those who do good will get good reward and those who sow bad will reap bad reward. For the protagonist, the death of his father is because his father did not do good things during his life:

\footnotetext{
Kocap nuju sawijining dina Babatan geger. Ketemune bapak tiwas kajugrugan longsoran punthuk kang lagi dikeruk alat berat. .... Oh, bapak. Teka kaya mangkono kang dadi undhuhundhuhaning pakartine...

(Harjono, 2018b, p. 24)

(One day Babatan was chaotic. People found my father dead, deeply buried in the collapsed hill being excavated. .... Oh, Dad. I do not expect that you will end up this way because of what you did ...)
}

Despite knowing everything, the protagonist does not say or do anything. It could be that he feels powerless, has no agency or he just does not care at all. This attitude is not necessarily wrong. In Java, common people do not always have the courage or lack the agency to say or do good things for other people. Or, often times, people do not say anything because they want to maintain social harmony or rukun, "an ideal standard for social relationships meaning harmony, co-operation, unity of effort, minimization of conflicts" (Geertz, 1961, pp. 47-8). The story provides an insight into the mindset of a people and community that is willing to tolerate injustices and tragedies at the expense of avoiding conflicts and confrontations, hence perpetuating social and political conditions that do not benefit them ultimately.

\section{CONCLUSION}

Based on my analysis, it can be concluded that the four selected short stories contain sociopolitical issues in Indonesia, i.e., democracy, people's power, equality, and corruption even though each short story has its own emphasis. These four short stories may not be enough to describe contemporary Javanese literary works in general. However, abundant works in the form of poetry, short story, and novel need to be researched to justify that contemporary Javanese literature undoubtedly describes Javanese society in particular and Indonesian society in general and whether it has socio-political engagements. With the Internet and increasingly advanced communication technology, Javanese literary publishing, which was on the verge of collapse for at least two decades, is now re-emerging. Young authors are rising and they publish their works independently.

There is no room in this paper to discuss many current works of Javanese literature. Therefore, this paper can be considered as an opening to introduce contemporary Javanese literature to the international level. In addition to Anderson (1990) and Quinn (1983; 1992), other experts in Javanese language and culture are expected to be interested in researching contemporary Javanese literature as well as other regional literatures in Indonesia. The literature of a nation is a reflection of its society in a certain era. By researching contemporary Javanese literature, one will be able to understand the current condition of Javanese society. The discussion of the four short stories above shows that contemporary Javanese literature is rich in socio-political content. Therefore, intensive research on Javanese literature is needed to understand the Javanese society. Besides, it will also have a positive impact on the development and revitalization of Javanese literature.

Many topics can still be explored for further research in contemporary Javanese literature. Future researchers can focus on poetry, short story or novel within a certain period 
of time by using different approaches or theories. In the perspective of the sociology of literature, until now there has not been serious research in the sociology of readers. This is a gap that needs to be filled through further research.

\section{REFERENCES}

Ajidarma, S. G. (2003). Penembak Misterius. Yogyakarta: Pabrik Tulisan.

Akbar, S. A. (2019). Kritik Sosial atas Rezim Orde Baru dalam Kumpulan Cerpen Penembak Misterius Karya Seno Gumira Ajidarma: Kajian Sosiologi Sastra Marx. Fenomena. 2(2), 114-131.

Anderson, B. R. O'G. (1965). Mythology and the Tolerance of the Javanese. Ithaca, New York: Cornell University.

Anderson, B. R. O’G. (1990). Language and Power: Exploring Political Cultures in Indonesia. Ithaca, NY: Cornell University Press.

Arendt, H. (1970) On Violence. Orlando and London: Harvest Books.

Atmowiloto, A. (1989). Perkawinan Batin Antara Sastra Daerah dan Sastra Nasional. In P.A. Prawoto (Ed.). Kritik Esai Kesusastraan Jawa modern (pp. 44-50). Bandung: Angkasa.

Brandon, J. R. (1970). On Thrones of Gold: Three Javanese Shadow Plays. Cambridge, MA: Harvard University Press.

Brata, S. (2001). Trem: Antologi Crita Cekak. Yogyakarta: Pustaka Pelajar.

Brata, S. (2003). Sastra Jawa Tanpa Buku. Panjebar Semangat No. 30, 26 July.

Budianto, I.S. (2018). Durmogati. Panjebar Semangat, No. 15, April 14, 23-24 to be continued to 26 .

Budiman, A. (2006). Kebebasan, Negara, Pembangunan: Kumpulan Tulisan 1965-2005. Jakarta: Kerja sama Freedom Institute dan Pustaka Alvabet.

Budiman, M. (2011). Ethnicity and the Performance of Identity. Wacana, 13(2), 233-255.

Budiono A. E. D., E. (2018). Maju Tatu Mundur Ajur. Panjebar Semangat, No. 18, May 5, 23 24.

Calinescu, M. (1982). Literature and Politics. In J. P. Barricelli and J. Gibaldi (Eds.). Interrelations of Literature (pp. 123-149). New York: The Modern Language Association of America.

Cambridge Dictionary online. (2021). elite. Retrieved July 20, 2021 from https://dictionary.cambridge.org/dictionary/english/elite

Clara Ng. (2006). Dimsum Terakhir. Jakarta: Gramedia Pustaka Utama.

Darmaningtyas (2005). Pendidikan Rusak-rusakan. Yogyakarta: LKIS.

Dwiastono, R., and Priambodo, O. B. (May 28, 2029). Pemilu 2019: Kisah para caleg gagal, dari yang gangguan jiwa hingga yang tidak kapok. Retrieved August 20, 2021 from https://www.bbc.com/indonesia/indonesia-48419608

Esmiet. (1977). Tunggak-tunggak Jati. Jakarta: Pustaka Jaya.

Eswe, K. (1991). Novel Jawa Saku: Sebuah Kritik. In In P. A. Prawoto (Ed.). Keterlibatan Sosial Sastra Jawa Modern (pp. 78-84). Solo: PT. Tri Tunggal Tata Fajar.

Foucault, M. (1998). The History of Sexuality: An Introduction Vol. 1. New York: Vintage Books.

Gaus, A. (2009). Sang Pelintas Batas: Biografi Djohan Effendi. Jakarta: Kerja sama Indonesian Conference on Religion and Peace [dan] Penerbit Buku Kompas.

Geertz, C. (1960). The Religion of Java. New York: The Free Press of Glencoe, Inc.

Geertz, H. (1961). The Javanese Family: A Study of Kinship and Socialization. New York: The Free Press of Glencoe, Inc.

Harjono, S.A. (2018a). Bojo. Panjebar Semangat No. 26, June 30, 23-24. 
Harjono, S.A. (2018b). Apik Meneng. Panjebar Semangat, No. 34, August 25 30, 23-24 to be continued to 50 .

Hutomo, S. S. (1975). Telaah Kesusastraan Jawa Modern. Jakarta: Pusat Pembinaan dan Pengembangan Bahasa Departemen Pendidikan dan Kebudayaan.

Hutomo, S. S. (1991). Susastra Indonesia Sebagai "Susastra Pemersatu" Susastra Daerah Bangsa Indonesia. In P. A. Prawoto (Ed.). Keterlibatan Sosial Sastra Jawa Modern (pp. 20-40). Solo: PT. Tri Tunggal Tata Fajar.

Hutomo, S. S. (1997). Sosiologi Sastra Jawa. Jakarta: Balai Pustaka.

Jatmiko, D. (2016). Strategi Literer Suparto Brata dalam Kontestasi Simbolik Arena Sastra Indonesia. Mozaik Humaniora, 16(1), 24-41.

Krippendorff, K. (2004). Content Analysis: An Introduction to Its Methodology. Thousand Oaks, CA: SAGE.

Kristianawati, A. (2016, September 4). Sastra Jawa Telah Mati. Surabaya, Indonesia: Jawa Pos Newspaper.

Madasari, O. (2010). Entrok. Jakarta: Gramedia Pustaka Utama.

Magnis-Suseno. (1988). Etika Jawa: Sebuah Analisa Falsafi Tentang Kebijaksanaan Hidup Jawa. Jakarta: PT Gramedia.

Margono, Y. B. (2004). Cerkak-cerkake Panjebar Semangat Taun 2003. Panjebar Semangat, No. 9 and 10, February 28 and March 3.

Margono, Y. B. (2020). Maca Geguritan ing Amerika: Antologi Esai Sastra Jawa Modern. Semarang: Sint Publishing.

Mazrieva, E. (January 30, 2019). Indeks Persepsi Korupsi Indonesia Naik, Bukti Keseriusan Pemberantasan Korupsi? Retireved February 5, 2020 from https://www.voaindonesia.com/a/indeks-persepsi-korupsi-indonesia-naik-buktikeseriusan-pemberantasan-korupsi-/4764712.html

Mudjiharto, M. (2020). Menyimak Perkembangan Sistem Manajemen Pemerintahan Negara RI Era Reformasi. Jurnal Mitra Manajemen, 5(1).

Phillips, H. P. (1987). Modern Thai Literature: With an Ethnographic Interpretation. Honolulu: University of Hawaii Press.

Pratiwi, D. A., Safitri, I., \& Farika, L. (2019). Kritik Sosial Dalam Kumpulan Puisi W. S. Rendra: Kehidupan masyarakat di Indonesia. Cakrawala Linguista, 1(2), 59-67.

Quinn, G. (1983). The Case of the Invisible Literature: Power, Scholarship, and Contemporary Javanese Writing. Indonesia, 35, 1-36.

Quinn, G. (1992). The Novel in Javanese. Leiden: KITLV Press.

Ragilputra, T. (2007). Bledheg Segara Kidul: Antologi Geguritan, 1987-2007. Yogyakarta: Gema Grafika, 2007.

Riyanto, W. J., (Ed.). (2019). Inventarisasi Data Kesenian Jawa Tengah: Sastrawan. Semarang: Taman Budaya Jawa Tengah.

Rokhmansyah, A. (2015). Orde Baru Sebagai Landasan Fabula dalam Novel Entrok Karya Okky Madasari: Kajian Formalisme Rusia. CaLLs, 1(1), 39-51.

Rokib, M. (2015). Reading Popular Islamic Literature: Continuity and Change in Indonesian Literature. Heritage of Nusantara: International Journal of Religious Literature and Heritage, 4(2), 183-194.

Scott, J. C. (1985). Weapons of the Weak: Everyday Forms of Peasant Resistance. New Haven, CT: Yale University Press.

Suharyo, S. (2018). Nasib Bahasa Jawa dan Bahasa Indonesia dalam Pandangan dan Sikap Bahasa Generasi Muda Jawa. Nusa: Jurnal Ilmu Bahasa dan Sastra, 13(2), 244-255.

Suharyono, A. Y. (2001). Sirah! Jakarta: Penerbit Wedatama Widya Sastra.

Sumardjo, J. (1991). Sastra Minoritas. In P. A. Prawoto (Ed.). Keterlibatan Sosial Sastra Jawa Modern (pp. 15-19). Solo: PT. Tri Tunggal Tata Fajar. 
Sumardjo, J. (2016). Politik Partisan dalam Sejarah Sastra Indonesia. In Setiajid, (Ed.). Prosiding Seminar Nasional Sastra dan Politik Partisan. Yogyakarta: Himpunan Sarjana Kesusastraan Indonesia Komisariat Universitas Sanata Darma, 1-9.

Susanti, N., Supriatna, N., \& Sumantri, Y. K. (2019). Lekra Vs Manikebu: Perlawanan Majalah Sastra Terhadap Politik Kebudayaan Pemerintah Masa Demokrasi Terpimpin (19611964). Factum: Jurnal Sejarah dan Pendidikan Sejarah, 8(1), 97-112.

Suyatno, S. (2011). Sajak-sajak Realisme Sosialis Lekra: Kajian Tematik. Humaniora, 23(1), $1-11$.

Taher, A.P. (2019). KPK: Salah Satu Alasan Banyak Suami Jadi Koruptor Karena Istrinya. Retrieved February 10, 2020 from https://tirto.id/kpk-salah-satu-alasan-banyaksuami-jadi-koruptor-karena-istrinya-diBQ

Tanjung, A. (2007). The Golkar Way. Jakarta: Gramedia Pustaka Utama.

Taum, Y. Y. (2016). Sastra dan Tanggung Jawabnya Dalam Negara Orde Baru. In Setiajid, (Ed.). Prosiding Seminar Nasional Sastra dan Politik Partisan. Yogyakarta: Himpunan Sarjana Kesusastraan Indonesia Komisariat Universitas Sanata Darma, 10-25.

Tondo, H. (2009). Kepunahan Bahasa-bahasa Daerah: Faktor Penyebab dan Implikasi Etnolinguistis. Jurnal Masyarakat dan Budaya, 11(2), 277-296.

Wellek, R., and Warren, A. (1948). Theory of Literature. Orlando, FL: Harcourt, Brace \& Company.

Widayat, A. (2005). Suksesi dalam Sastra Jawa Modern. In Mulyana (Ed.). Demokrasi dalam Budaya Lokal. Yogyakarta: Tiara Wacana.

\section{ABOUT THE AUTHOR}

Yosep B. Margono-Slamet, $\mathrm{PhD}$ is an Associate Professor in the English Department of the Faculty of Languages and Culture, The University of 17 Agustus 1945 Semarang. His research interest covers English Literature, Indonesian Literature, and Javanese Literature. Currently he teaches Creative Writing, Academic Writing, Multicultural Literature, and British and American Studies. 